\title{
DEPRESSION OF LACTOSE HYDROLYSIS BY YEASTS
}

\author{
D. A. Berman AND R. J. Sobieski* \\ Department of Biology, Wichita State University, Wichita, \\ Kansas 67208, USA
}

\begin{abstract}
$C_{A N D I D A}$ ALBICANS is an opportunistic pathogen and has been isolated from the alimentary tracts of about a third of the infants suffering from acute gastroenteritis (Bishop and Barnes, 1974). These workers associated a significant decrease of disaccharidase activity with yeast growth in the duodenum and they found that $C$. albicans caused a depression of lactase activity in ligated segments of the small intestine of infant rabbits. They concluded that lactase depression was not due to mycelial penetration of epithelial cells by the yeast, but to damage of the intestinal epithelial cells caused by growth of the organism in the lumen of the gut.

To investigate the possible effect of this phenomenon on virulence, depression of lactase activity by pathogenic and non-pathogenic yeasts was studied by those methods. The first was an in-vitro assay involving yeasts and purified $\beta$-galactosidase ( $\beta$-gal). In the other two methods infant-rabbit small intestine was used, either in the live animal or after isolation in a physiological bath.
\end{abstract}

\section{MATERIALS AND METHODS}

Microbiology. Strains 1 and 2 of $C$. albicans were obtained from adult hospital patients with candiduria and a laboratory strain, (no. 526) was supplied by A. Sarachek of this department; a strain of the rarely pathogenic Saccharomyces cerevisiae was obtained from the department culture collection. Organisms were maintained, grown and enumerated as described by Sobieski and Brewer (1976). After overnight incubation, cells in the exponential phase of growth were washed and resuspended in appropriate concentrations in fresh medium.

The content of each ligated rabbit-intestinal loop was sampled both for microscopical evaluation and for culture. Microbial changes were studied by incubating at $37^{\circ} \mathrm{C}$, aerobically and anaerobically, cutlures on sheep blood agar, tryptone-glucose-yeast extract agar (Sobieski and Olsen, 1973), MacConkey's agar and Sabouraud's agar and in cooked meat medium.

Experimental animals. Infant albino rabbits aged 15 days were deprived of food for $48 \mathrm{~h}$ but given water ad libitum. Anaesthesia was then induced by intraperitoneal injection of Nembutal and maintained with ether and oxygen. The surgical procedure was identical to that described by Bishop and Barnes (1974), except that loops were inoculated with 0.5-ml volumes of yeast or broth medium. Loops inoculated with $5 \times 107$ viable or autoclaved yeast cells were separated by loops inoculated with medium alone. After completion of the surgical procedure, the rabbits were deprived of food for $10 \mathrm{~h}$ and then killed. Other rabbits were starved for $48 \mathrm{~h}$ before being killed to supply ligated small intestine for use in a physio-

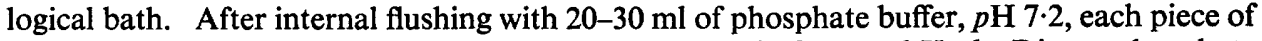
intestine was maintained for $20 \mathrm{~h}$ at $37^{\circ} \mathrm{C}$ in $300-320 \mathrm{ml}$ of aerated $\mathrm{Krebs}-\mathrm{Ringer}$ phosphate solution (Tharp, 1972) containing penicillin $\mathrm{G}, 631$ units per $\mathrm{ml}$, and streptomycin, $50 \mu \mathrm{g}$ per $\mathrm{ml}$. After incubation, the ligated loops from both types of intestinal assay were sampled microbiologically as already described. Loops were then placed in separate screw-capped

Received 3 Feb. 1976; revised version accepted 15 Sept. 1976.

* Present address: Department of Biological Science, Emporia Kansas State College, Emporia, Kansas 66801, USA.

Reprint requests to R. J. S.

J. MED. MICROBIOL.-VOL. 10 (1977) 
TABLE I

Depression of $\beta$-galactosidase activity by yeasts

\begin{tabular}{l|cc}
\hline \multicolumn{1}{c|}{ Yeast } & $\begin{array}{c}\text { *Percentage depression of activity } \\
\text { in assay mixtures }\end{array}$ \\
\hline & $\overbrace{\begin{array}{c}\text { immediately, } \\
\text { at } 4^{\circ} \mathrm{C}\end{array}}^{\begin{array}{c}\text { after } 75 \mathrm{~min} ., \\
\text { at } 22^{\circ} \mathrm{C}\end{array}}$ \\
$\begin{array}{l}\text { C. albicans, strain 1 } \\
\begin{array}{l}\text { C. albicans, strain 2 } \\
\text { S. cerevisiae }\end{array}\end{array}$ & $>99$ & 75 \\
\hline
\end{tabular}

* Percentage depression is expressed in terms of the activity of yeast-free controls incubated for $75 \mathrm{~min}$. and the values are the means of at least three experiments.

tubes, stored at $-20^{\circ} \mathrm{C}$ and later assayed. Homogenates of loop sections were made in $3.5-\mathrm{ml}$ volumes of $0.06 \mathrm{M}$ phosphate buffer, $p \mathrm{H} \mathrm{7.2}$, by means of pestle, mortar and sand. The buffer was prepared by adding $61.1 \mathrm{ml}$ of $\mathrm{Na}_{2} \mathrm{HPO}_{4}$ solution $(8.51 \mathrm{~g}$ per litre) to $38.9 \mathrm{ml}$ of $\mathrm{KH}_{2} \mathrm{PO}_{4}$ solution (8.16 $\mathrm{g}$ per litre). No differences in enzymatic activity before and after freezing for 12-14 days were noted.

Enzyme assays. All assays for lactase activity were done by means of the basic method of Dahlqvist (1964) as embodied in the Glucostat Reagent Set (Worthington Biochemical Corp., Freehold, New Jersey). For in-vitro studies of the effects of yeast on enzyme activity, the assay mixture contained (per $\mathrm{ml}$ ): $0.8 \mathrm{ml}$ of $1.25 \%$ lactose in $0.2 \mathrm{M}$ acetate buffer, $p \mathrm{H} 4.2$; $0.1 \mathrm{ml}$ of a solution of $\beta$-gal (Calbiochem) containing $71.4 \mu \mathrm{g}$ per ml; $0.1 \mathrm{ml}$ yeast suspension $\left(5 \times 10^{7}\right.$ cells). After incubation at room temperature $\left(22^{\circ} \mathrm{C}\right)$ for $75 \mathrm{~min}$., enough $0 \cdot 1 \mathrm{~N} \mathrm{KOH}$ was added to raise the $p \mathrm{H}$ to $6 \cdot 5-7 \cdot 0$, and the final volume was made up to $2.0 \mathrm{ml}$ with water. After clarification by low-speed centrifugation, the amount of glucose liberated by the enzyme was determined by the semi-microassay method described with the Glucostat Reagent Set, except that $\mathrm{Ba}(\mathrm{OH})_{2}$ and $\mathrm{ZnSO}_{4}$ were not needed. Necessary controls established the linearity of the activity of the purified enzyme during the incubation period and the assay's linearity in glucose detection over the range $0-0.4 \%$. In enzyme assays on ligated intestinal loops, $0 \cdot 1-\mathrm{ml}$ samples from the homogenised sections were used, together with $0.8 \mathrm{ml}$ of $1.25 \%$ lactose in $0.06 \mathrm{M}$ phosphate buffer, $p \mathrm{H} 7.2$, and $1.1 \mathrm{ml}$ of the $0.06 \mathrm{M}$ phosphate buffer. After the $75 \mathrm{~min}$. incubation period, the glucose levels were determined on clarified supernates. When the contents of comparable control loops were taken from different rabbits used in either test system and assayed for lactase activity, it was found that the activity varied little and was directly proportional to the wet weight of the loop.

Evaluation of results. No ligated loop had to be rejected because of loop distension or infarction. No increases were noted in the numbers of any pathogenic organism, and no rabbit had to be rejected for consistently low levels of lactase activity in control loops. All enzyme assays on test and control samples were done at least in duplicate and usually in quadruplicate. To facilitate comparisons between the three assay systems used, all results are expressed as a percentage reduction of enzyme activity in terms of the activity found in the yeast-free controls in the same assay. To overcome a slight variation in the levels of lactase activity in the broth control loops in different parts of the small intestine, the mean enzyme activity (per g, wet weight) in the broth control loops on either side of the experimental loop was determined.

\section{RESULTS}

The enzyme $\beta$-gal is but one of three in mammalian intestine able to hydrolyse the $\beta$ glycosidic linkage in carbohydrates (Hsia et al., 1966; White, Handler and Smith, 1973). Both $C$. albicans and $S$. cerevisiae significantly depressed the activity of this enzyme (table I). 
TABLE II

Depression of lactase activity by yeasts, in the ligated gut of intact infant rabbits and in isolated gut preparations

\begin{tabular}{|c|c|c|c|c|}
\hline \multirow{2}{*}{ Test system } & \multirow{2}{*}{ Yeast } & \multicolumn{2}{|c|}{$\begin{array}{l}\text { Number of gut loops } \\
\text { inoculated with }\end{array}$} & \multirow{2}{*}{$\begin{array}{l}\text { Percentage } \\
\text { depression } \\
\text { of activity" }\end{array}$} \\
\hline & & yeasts & $\begin{array}{l}\text { medium } \\
\text { alone }\end{array}$ & \\
\hline $\begin{array}{l}\text { GIR } \\
\text { GIR }\end{array}$ & $\begin{array}{l}\text { Live } C \text {. albicans } \\
\text { Live } S . \text { cerevisiae }\end{array}$ & $\frac{2}{2}$ & $\begin{array}{l}4 \\
4\end{array}$ & $\begin{array}{l}47 \\
44\end{array}$ \\
\hline $\begin{array}{l}\text { IGP } \\
\text { IGP } \\
\text { IGP }\end{array}$ & $\begin{array}{l}\text { Live } C \text {. albicans } \\
\text { Dead } C \text {. albicans } \\
\text { Live } S \text {. cerevisiae }\end{array}$ & $\begin{array}{l}7 \\
3 \\
5\end{array}$ & $\begin{array}{r}14 \\
6 \\
10\end{array}$ & $\begin{array}{l}50 \\
48 \\
37\end{array}$ \\
\hline
\end{tabular}

Strain 526 of C. albicans was used.

GIR = Gut of intact rabbit; IGP = isolated gut preparation.

* Expressed in terms of the activity in control gut loops.

It is concluded that yeasts bind the enzyme without undergoing active metabolism or requiring prolonged contact, because immediate centrifugation of the refrigerated mixtures of yeast, enzyme and lactose demonstrated the greater depression of enzyme activity. However, the $62-75 \%$ inhibition demonstrated after incubation was still substantial. Supernates from overnight cultures did not depress enzyme activity, and increasing the yeast cell numbers by factors of 10-100 had no effect (data not shown). Furthermore, depression of $\beta$-gal activity by dead cells of $C$. albicans strain 526 was similar to that produced by living cells: in four experiments the percentage reductions in activity by autoclaved cells were $42,44,32$ and 58, while the corresponding figures for living cells were 37, 44, 27 and 52.

Infant rabbits yielded 57 ligated loops that met the test criteria (see Methods). These loops were distributed between experiments with living rabbits and those with isolated gut preparations. The yeasts tested depressed lactase activity in both test systems (table II), although the depression by living $S$. cerevisiae was not as great in the physiological bath as it was in the living animal.

\section{Discussion}

Bishop and Barnes (1974) reported disaccharide intolerance as a sequel of acute gastroenteritis caused by Candida albicans. Although $\beta$-gal is but one of three enzymes able to hydrolyse the $\beta$-glycosidic linkage in lactose, more enzymatic activity was removed by yeast in vitro (table I) than in test systems involving ligated gut segments in which all three enzymes would have been present. As the relative amounts of each enzyme in the intestinal tract are uncertain, $\beta$-gal, and not lactase, may be the main enzyme involved in vivo. Our studies with rabbit gut, and those of earlier authors, do not establish which enzymes are reduced in activity by yeasts. A possible interpretation of our results is that the disaccharide intolerance is associated with an effect of yeast on other enzymes acting on $\beta$-glycosidic linkages, besides those with prime specificity for lactose, and that the affected enzyme possesses a regulatory function over the other enzymes of this type.

The possibility that the phenomenon under investigation is concerned in the virulence of $C$. albicans seems remote because $S$. cerevisiae, which is rarely pathogenic, possessed a significant degree of inhibitory activity.

Our findings that living and dead cells of $C$. albicans caused a similar degree of enzyme depression in our test systems and that inhibition occurred rapidly at $4^{\circ} \mathrm{C}$ with living or non-living cells suggest that the yeast has a striking ability to bind rapidly to the enzyme and that the depression does not depend upon interaction with living cells. It may be that in vivo 
this is a mechanism of attachment to mucosal cells having the enzymes at their surfaces, but other factors must be involved in the pathogenicity of $C$. albicans at such sites.

The yeast-enzyme intraction depresses the activity of the disaccharidases and this is probably significant in the disaccharide intolerance seen as a sequal to the growth of $C$. albicans in the infant gut.

\section{SUMMARY}

To investigate the role that the known disaccharidase depression may play in the aetiology of infant gastroenteritis caused by Candida albicans, C. albicans and the rarely pathogenic, Saccharomyces cerevisiae were studied by three different methods. Both types of yeast significantly depressed the lactose-hydrolysis activity of $\beta$-galactosidase, and both depressed lactose hydrolysis in the ligated small intestine of infant rabbits, either in intact animals allowed to survive for $10 \mathrm{~h}$, or in a physiological bath for $20 \mathrm{~h}$. The depression of lactose activity was not temperature dependent; living and inactivated yeast preparations produced comparable degrees of depression of enzyme activity. It is concluded that the depression of lactose hydrolysis is not a virulence factor of $C$. albicans, but contributes to the often observed disaccharide intolerance associated with candida gastroenteritis in infants.

We gratefully acknowledge the expert technical assistance of J. M. Sobieski in these experiments with infant rabbits.

\section{REFERENCES}

Bishop, R. F. AND BARNes, G. L. 1974. Depression of lactase activity in the small intestine of infant rabbits by Candida albicans. J. med. Microbiol., 7, 259.

DAHLQVIST, A. 1964. Method for assay of intestinal disaccharidases. Analyt. Biochem., 7, 18.

Hsia, D. Y. Y., Makler, M., Semenza, G. ANd Prader, A. 1966. $\beta$-Galactosidase activity in human intestinal lactases. Biochim. biophys. Acta, 113, 390.

SOBIESKI, R. J. AND BREWER, A. R. 1976. Toxicity of nalidixic acid on Candida albicans, Saccharomyces cerevisiae and Kluyveromyces lactis. Antimicrob. Agents Chemother., 9, 485.

SOBIESKi, R. J. AND Olsen, R. H. 1973. Cold-sensitive Pseudomonas RNA Polymerase I. Characterization of the host dependent cold-sensitive restriction of phage CB3. J. Virol., 12, 1375.

Tharp, G. E. 1972. Experiments in physiology, 2nd ed., Minneapolis, p. A-27.

White, A., Handler, P. And Smith, E. L. 1973. Principles of biochemistry, 5th ed., New York, p. 414. 